\title{
Identification of biofloc microscopic composition as the natural bioremediation in zero water exchange of Pacific white shrimp, Penaeus vannamei, culture in closed hatchery system
}

\author{
Hidayah Manan ${ }^{1} \cdot J_{u l i a}$ Hwei Zhong Moh $^{1} \cdot$ Nor Azman Kasan ${ }^{2} \cdot$ Suhaimi Suratman $^{3}$ • \\ Mhd Ikhwanuddin ${ }^{1}$
}

Received: 13 December 2015/ Accepted: 9 May 2016/Published online: 16 June 2016

(c) The Author(s) 2016. This article is published with open access at Springerlink.com

\begin{abstract}
Study on the microscopic composition of biofloc in closed hatchery culture system was carried out to determine the interaction between the aggregation flocs in the bioremediation process for the decomposition and degradation of organic matter loaded in the shrimp culture tanks. The study was done for 105 days of culture period in zero water exchange. All of the organic loaded in the culture tanks identified comes from the shrimp feces, uneaten fed, and the decomposed macro- and microorganisms died in the culture tanks. All of the microscopic organisms in the biofloc were identified using Advance microscopes Nikon 80i. From the present study, there were abundances and high varieties of phytoplankton, zooplankton, protozoa, nematodes and algae species identified as aggregates together in the flocs accumulation. All of these microscopic organisms identified implemented the symbiotic process together for food supply, become the algae grazer, act as natural water stabilizer in regulating the nutrients in culture tank and serve as decomposer for dead organic matter in the water environment. Heterotrophic bacteria identified from Pseudomonas and Aeromonas family consumed the organic matter loaded at the bottom of culture tank and converted items through chemical
\end{abstract}

Mhd Ikhwanuddin

ikhwanuddin@umt.edu.my

Hidayah Manan

hidayahmanan6187@gmail.com

1 Institute of Tropical Aquaculture, Universiti Malaysia Terengganu, 21030 Kuala Nerus, Terengganu, Malaysia

2 School of Fisheries and Aquaculture Sciences, Universiti Malaysia Terengganu, 21030 Kuala Nerus, Terengganu, Malaysia

3 Institute of Oceanography and Environment, Universiti Malaysia Terengganu, 21030 Kuala Nerus, Terengganu, Malaysia process as useful protein food to be consumed back by the shrimp. Overall it can be concluded that the biofloc organisms identified really contributed as natural bioremediation agents in zero water exchange culture system to ensure the water quality in the optimal condition until the end of culture period.

Keywords Biofloc compositions - Organic matter . Bioremediation $\cdot$ Symbiotic process

\section{Introduction}

Bioremediation is a process where microorganisms were stimulated with nutrients and other chemicals to enable them to wipe out contaminants in the targeted area and break down the hazardous substances into less toxic or non-toxic substances (Das 2014). Microorganisms are considered as the first living organisms to have evolved and are adaptive with the ecological changes. Nowadays, the use of microorganisms such as bacteria as biodegradation and bioremediation agent has come to attention because of its ability to reduce hazard, success in degrading natural and synthetic substances and accumulating toxic compound (Karigar and Rao 2011). According to Das et al. (2006), microorganisms are responsible for carbon fixation, nitrogen fixation, methane metabolism and sulfur metabolism, thus controlling the biogeochemical cycle. Microorganisms are able to produce diverse metabolic enzymes that can assist for safe removal of contaminants either by direct destruction or converting to safer or less toxic intermediate (Dash and Das 2012). Any microorganisms used as bioremediation has to possess resistant genotype for the particular pollutant and because of it, microorganisms possess certain unique characteristic which make them suitable for bioremediation processes (Stelting et al. 2010). 
Biofloc technology (BFT) is a promising technology which promotes the retention of waste and its conversion to biofloc as natural food for shrimp in the aquaculture system (Panigrahi et al. 2014). Biofloc consists of microorganisms such as heterotrophic bacteria, algae (dinoflagellates and diatoms), fungi, ciliates, flagellates, rotifers, nematodes, metazoans and detritus that conglomerate together and perform symbiotic processes to maintain the water quality, maintain bio-security, support high density of shrimp culture and reduce water exchange in the aquaculture system. In the biofloc technology (BFT) application, protein is utilized as a feed for the shrimp when the heterotrophic microbe in the biofloc converts the nitrogenous waste in the culture tank from the uneaten feed into protein. Development of dense heterotrophic bacterial community rather than algae dominated will overcome the waste generated in the aquaculture system through in situ bioremediation (Panigrahi et al. 2014). By addition of cheap carbohydrate sources such as molasses or tapioca usually in ration around C: $\mathrm{N} 12-15: 1$ in the water column, biofloc will convert the toxic nutrients in the water to beneficial food sources for shrimp consumption. Avnimelech (2009) found out that in high stocking density and zero or minimal water exchange the additional carbon source encourage the development of heterotrophic bacteria in the pond or tank. Schneider et al. (2005) discovered that addition of organic nitrogenous waste, ammonium will be converted into bacterial biomass if $\mathrm{C}: \mathrm{N}$ ratio is balanced at ratio 10-15:1. Usually in BFT, heterotrophic bacteria are more dominant than nitrifying bacteria because of their higher growth rate and microbial biomass yield per substrate, thus making many fold increase of heterotrophic bacteria (Hargreaves 2006). Identification of the microscopic biofloc composition can help in better understanding the application of biofloc. From the identification of each class of organisms' function (phytoplankton as primary producer, zooplankton as the algae grazer, bacteria and protozoa as organic matter decomposer) that occurs in the zero water exchange culture system, the interaction happening between the organisms in the biofloc system can be understood. Because of the potential of biofloc technology for bioremediation in the aquaculture system, present study was conducted to identify the biofloc microscopic composition and to determine the biofloc performance as the natural bioremediation agent for removal of organic matter loader in the culture tank in zero water exchange system.

\section{Methodology}

\section{Experimental design}

Rounded tank with capacity 8 ton (height $=1.2 \mathrm{~m}$ and diameter $=3.3 \mathrm{~m}$ ) was stocked with Pacific White shrimp,
Penaeus vannamei, postlarvae at PL10 with density of 100 PL per cubic meter, $\mathrm{m}^{3}$. Six tanks were used in the experiment for treatments (T1, T2 and $\mathrm{T} 3$ and for control tanks, C1, C2 and C3). Molasses as carbohydrate or carbon sources at ratio C:N 10:1 were transferred to the treatment culture tank after being fermented for $24 \mathrm{~h}$ to boost the breakdown process by the bacteria or the microorganisms for biofloc formulation. Shrimp were cultured for 105 days until reaching harvested size at PL115. During the culture period, the microorganisms in the culture tank were sampled every week to identify the microorganism's composition in the biofloc aggregation in the closed and zero water exchange system. All water parameters were checked weekly for $\mathrm{pH}$, salinity, DO, TDS, and temperature using YSI multi-probe YSI 556 and nutrients (ammonia, nitrite, nitrate) were analyzed with spectrophotometer by ammonia-salicylate method (Standard Method 8155), nitrite diazotization method (Standard Method 8507) and nitratecadmium reduction method (Standard Method 8192) of (DR/2400 Procedure manual 2002).

\section{Sample collection}

$3 \mathrm{~L}$ of water sample from treatment tank was filtered using plankton net $20 \mu \mathrm{m}$ for microscopic plankton identification. For bacterial identification, sample water was pipetted out using micropipette and serial diluted until $10^{-5}$ for bacteria analysis. Sample for plankton analysis was left $24 \mathrm{~h}$ for the substrate to settle at the bottom and concentrated to $10 \mathrm{ml}$ of water sample and then preserved with $10 \%$ formalin. All water samples were taken back to laboratory for further analysis.

\section{Microbial identification}

Bacteria were isolated using trypticase soy agar (TSA) and selective agar thiosulphate-citrate-bile salts-sucrose agar (TCBS) for isolating Vibrio sp. The colony-forming unit (CFU) from fifth time serial dilution $\left(10^{-5}\right)$ was selected for colony counting. Gram staining also was done to identify Gram-positive and -negative bacteria. Catalase test was done to identify Gram-positive bacilli. API kit (Biomerieux) API20E and API 20NE were used to identify Gram-negative bacteria. Incubation box, tray and lid were prepared for the strip preparation. For the inoculum preparation, an ampule of API $\mathrm{NaCl} 0.85 \%(2 \mathrm{ml})$ was selected and 1-4 colonies of bacteria were picked up using inoculation loop from the agar plate and then suspension was prepared with the turbidity equivalent to $0.5 \mathrm{McFar}$ land. For the API 20NE strip inoculation, test nitrate reduction $\left(\mathrm{NO}_{3}\right)$ and $p$-nitrophenyl- $\beta$-D-galactopyranoside hydrolysis (PNPG) were inoculated by distributing the saline suspension into the tubes using Pasteur pipette. API 
AUX medium was added to approximately $200 \mu \mathrm{l}$ of the remaining suspension into the ampule and was homogenized well. Tubes and cupules of test glucose fermentation (GLU) and Phenyl-acetate assimilation test (PAC) were filled with the suspension. Mineral oil was added to the cupules of 3 tests (GLU), arginine hydrolysis (ADH), and urea hydrolysis (URE) until convex meniscuses formed. The incubation box was closed and incubated at $29 \pm 2{ }^{\circ} \mathrm{C}$ for $24 \mathrm{~h}$. After the incubation period, the strips were read by referring to the reading table. The reactions for (GLU, $\mathrm{ADH}$, URE, aesculin hydrolysis test (ESC)), gelatine hydrolysis (GEL) and (PNPG) were recorded on result sheet. For $\mathrm{NO}_{3}$ test, 1 drop of NIT 1 and 1 drop of NIT 2 reagents were added to $\mathrm{NO}_{3}$ cupule. For tryptophan deaminase test (TRP), 1 drop of JAMES reagent was added and immediate reaction took place. NIT 1, NIT 2 and JAMES reagents were removed using pipette and test $\mathrm{NO}_{3}$ and TRP were covered with mineral oil. Kit was reincubated at $29 \pm 2{ }^{\circ} \mathrm{C}$ for $24 \mathrm{~h}$ and all tests were read again except for $\mathrm{NO}_{3}$, TRP and underlined GLU, which were only read once at $24 \mathrm{~h}$. Identification is obtained with the numerical profile. Database (V6.0) in the API web index was used by entering the seven digit numerical profile in the identification software for species identification.

For API20E strip inoculation, bacterial suspension were distributed into the tubes with pipette for citrate assimilation test (CIT), Voges-Proskauer (VP) test for acetyl methyl carbinol detection, gelatine hydrolysis (GEL) test by filled in both tube and cupules, and for test $\mathrm{ADH}$, lysine decarboxylase test (LDC), Ornithine decarboxylase test (ODC) and production of hydrogen sulfide test $\left(\mathrm{H}_{2} \mathrm{~S}\right)$ and urea hydrolysis (URE) filled with mineral oil in the cupules. The incubation box was closed and incubated at $36 \pm 2{ }^{\circ} \mathrm{C}$ for $18-24 \mathrm{~h}$. The strip was read by referring the reading table after incubation period. For Tryptophan deaminase test (TDA), 1 drop of TDA reagent was added, for Indole production test (IND) 1 drop of JAMES reagent was added and for VP test, VP 1 and VP 2 reagents were added. Identification is obtained with numerical profile nine digit using the database (v4.1) in the API web index for species identification.

\section{Plankton microscopic identification}

Advance microscope Nikon $80 i$ was used for biofloc microscopic identification and for plankton length and size measurements. Qualitative and quantitative analyses of phytoplankton and zooplankton were done by Lackey's method. Compound microscope was used for phytoplankton counting. The cover slip was placed over a drop of water in the slide and whole of cover slip was examined by parallel overlapping strips to count all the organisms in the drop. About 22 strips were examined in each drop. Number of subsamples to be taken depended on examining 2-3 successive subsamples without addition of an encounter species when compared to the examined subsamples in the same sample (American Public Health Association APHA 1989).

Calculation formula:

$$
\begin{aligned}
\text { Density }\left(\text { cells } 1^{-1}\right)= & \frac{C \times \mathrm{A}_{\mathrm{t}}}{\mathrm{A}_{\mathrm{s}} \times S \times V} \\
& \times \frac{\text { volume of concentrated sample }(\mathrm{ml})}{\text { volume of actual water filtered }}
\end{aligned}
$$

where $C$ Number of organisms counted, $\mathrm{A}_{\mathrm{t}}$ Area of cover slip (22 mm $\times 22 \mathrm{~mm}), S$ Number of strip counted, $\mathrm{A}_{\mathrm{s}}$ Area of strip (22 $\mathrm{mm} \times 1 \mathrm{~mm}), V$ Volume of sample under the cover slip.

\section{Results}

There were various types of microscopic organisms identified from bioflocculation. All of the microscopic organisms identified come from different classes of phytoplankton algae and also numerous of algae grazer such as rotifer and nematode also the protozoa, Vorticella sp. (Fig. 1). From Gram staining, rod-shaped Gram-positive bacteria were also identified, which are Bacillus sp., from the positive result of catalase test. From the API kit analysis, species of bacteria identified come from heterotrophic bacteria (Aeromonas hydrophila, Pseudomonas aeruginosa) and also anaerobic bacteria, Vibrio sp. (ex. V. fluvialis). For the water parameter results, mean dissolved oxygen, DO, was $6.67 \pm 0.97 \mathrm{mg} \mathrm{l}^{-1}$ (5.9-9.53 $\left.\mathrm{mg} \mathrm{l}^{-1} ; n=12\right)$, mean temperature $28 \pm 0.30{ }^{\circ} \mathrm{C}$ $\left(26-28^{\circ} \mathrm{C} ; \quad n=12\right)$, mean $\mathrm{pH} 7.36 \pm 0.49$ (6.1-8.2; $n=12)$, mean salinity $33.66 \pm 1.45 \mathrm{ppt} \quad(31-36 \mathrm{ppt}$; $n=12$ ) and mean total dissolved solid, TDS $33.52 \pm 1.33$ (31.5-35.5 $\mathrm{mg} \mathrm{l}^{-1} ; n=12$ ). The bioremediation process was successfully carried out by the microorganism in the biofloc as the nutrients ammonia, $\mathrm{NH}_{3}$, drops from 8.0 to $0.3 \mathrm{mg} \mathrm{l}^{-1}$, nitrite drops from 0.8 to 0.5 , and nitrate drops from 15.3 to $5.7 \mathrm{mg} \mathrm{l}^{-1}$ during the culture period (Fig. 2). Species Pseudomonas sp. and Aeromonas sp. were identified to be dominant from the colony-forming unit (CFU) counting. Vibrio sp. was also identified as aggregates in the bioflocculation (Table 1). The percentage of bacteria identified dominantly come from heterotrophic bacterial species (ex. Aeromonas hydrophyila) and also from Vibrio spp. (V. alginolyticus and V. fluvialis) (Fig. 3). There were a lot of and varieties of microscopic organism compositions identified from bioflocculation in treatment tank 1 (Table 2) treatment tank 2 (Table 3) and treatment tank 3 (Table 4). The density of microorganism was also identified based on the Day of Culture (DOC) of shrimp, density of microorganism in DOC11 shrimp (Fig. 4), DOC17 (Fig. 5), DOC30 (Fig. 6), DOC58 (Fig. 7), DOC65 (Fig. 8), DOC76 (Fig. 9), and for DOC93 (Fig. 10). 

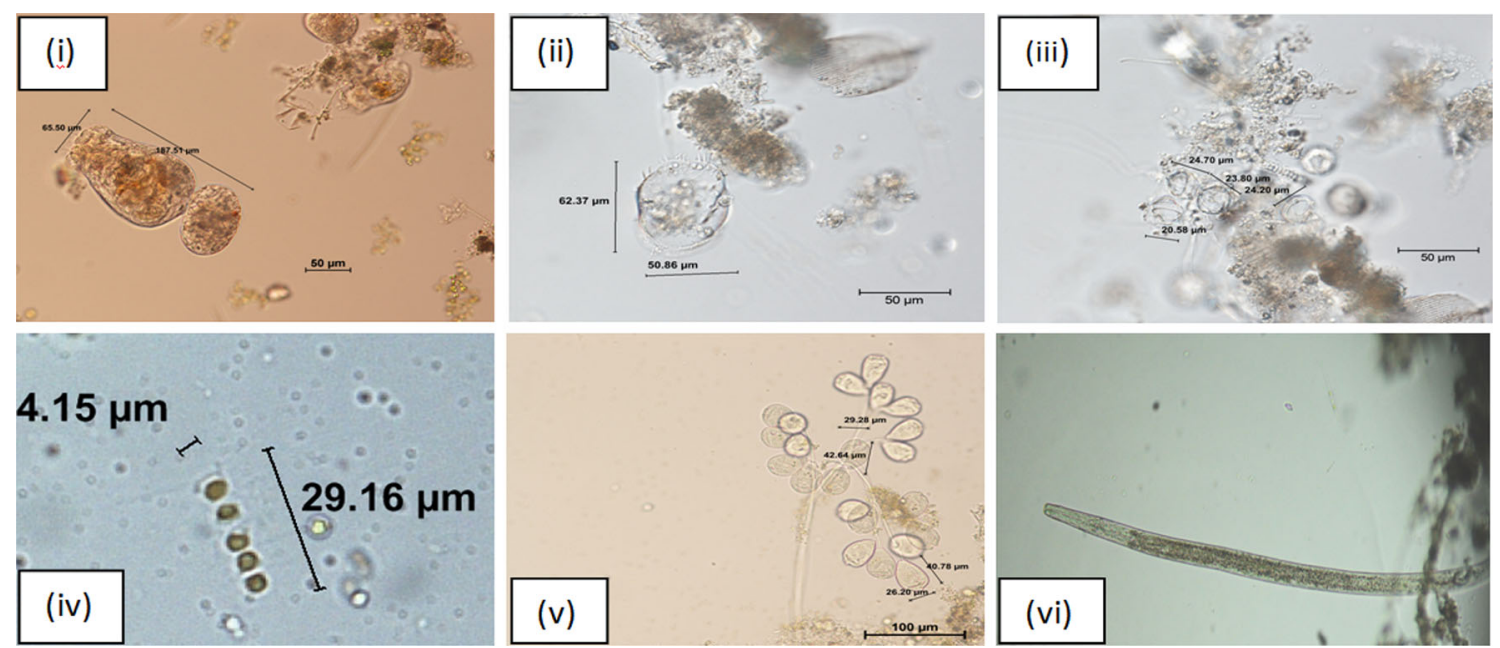

Fig. 1 Microscopic organisms identified in the floc: a rotifer; b euplotes, the ciliate protozoa; c Alexandrium sp. of dinoflagellates; d chaetoceros diatom; e vorticella the protozoa and $\mathbf{f}$ nematode. All observed under $\times 400$ magnifications

Fig. 2 The bioremediation process was successfully carried out by microorganisms in the biofloc (bacteria, algae, plankton) to breakdown the hazardous nutrients in the treatments culture tank into the non-toxic substances and can be consumed back as additional protein feed diet for shrimp consumption

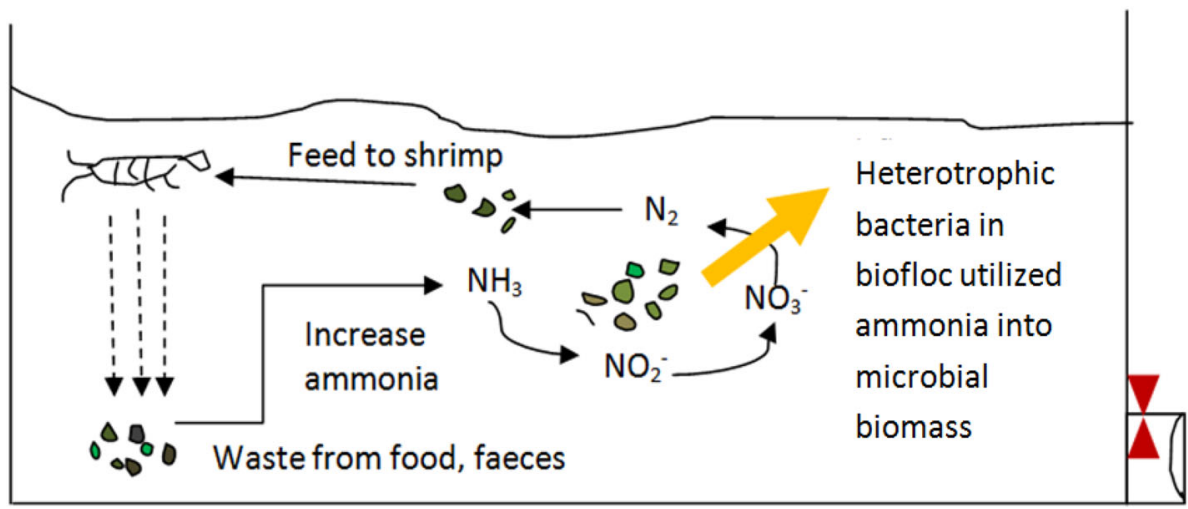

Table 1 Species of Gram-negative bacteria identified using API kit 20E and 20NE biomerieux

\begin{tabular}{|c|c|c|c|c|c|c|c|}
\hline Tank & Colony & CFU count & Species identify & $\%$ id & Id status & Code & API \\
\hline \multirow[t]{3}{*}{ Tank 1} & \multirow[t]{3}{*}{3 colony } & $5 \times 10^{-5}$ & Vibrio fluvialis & 98.3 & Good id & $204650 * * *$ & $20 \mathrm{E}$ \\
\hline & & $8 \times 10^{-5}$ & Vibrio alginolyticus & 82.6 & Good id & $7010 * * *$ & $20 \mathrm{NE}$ \\
\hline & & $23 \times 10^{-5}$ & Aeromonas hydrophila & 98.9 & Good id & $704612 * * *$ & $20 \mathrm{E}$ \\
\hline \multirow[t]{2}{*}{ Tank 2} & \multirow[t]{2}{*}{2 colony } & $13 \times 10^{-5}$ & Aeromonas hydrophila & 98.4 & Good id & $704612 * * *$ & $20 \mathrm{E}$ \\
\hline & & $34 \times 10^{-5}$ & Aeromonas salmonicida & 99.9 & Very good id & $1550 * * *$ & $20 \mathrm{E}$ \\
\hline \multirow[t]{3}{*}{ Tank 3} & \multirow[t]{3}{*}{3 colony } & $38 \times 10^{-5}$ & Aeromonas salmonicida & 99.9 & Very good id & $1550 * * *$ & $20 \mathrm{NE}$ \\
\hline & & $16 \times 10^{-5}$ & Pseudomonas aeruginosa & 98.9 & Good id & $220200 * * *$ & $20 \mathrm{E}$ \\
\hline & & $3 \times 10^{-5}$ & Vibrio alginolyticus & 86.3 & Good id & $7434 * * *$ & $20 \mathrm{NE}$ \\
\hline
\end{tabular}

*** Profile coding of the analytical profile index

\section{Discussions}

From the identifications done on the biofloc aggregations, the microorganisms can be divided into five overlapping groups which are: floc-forming organisms, saprophytes (organisms that obtain nutrients from dead organic matter), nitrifying bacteria, algae grazers, and pathogenic bacteria
(Vibrio spp). All of these types of microorganisms have their own function and interaction between each other in the biofloc system to make the bioremediation process successfully happen. The organisms that forming the floc were identified come from some of algae and bacterial biomasses which they used in activated sludge form the organic matter come from the waste in the tank to secrete sticky EPS 
Fig. 3 Percentage of bacterial species identified accumulated together in the biofloc in treatment tank 1 (T1), tank 2 (T2) and tank 3 (T3)

\section{Species of Gram -ve bacterial \% identified}

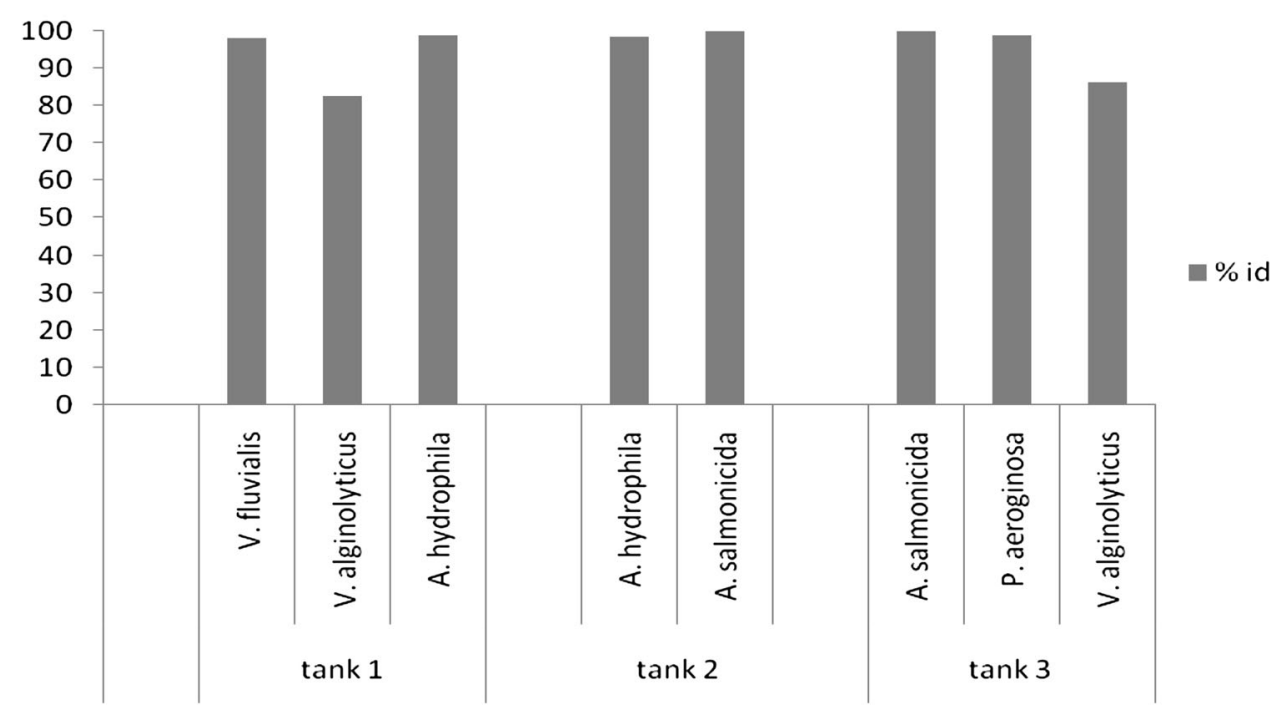

Table 2 Type of microorganisms identified as aggregates in the biofloc in Tank 1

\begin{tabular}{|c|c|c|c|c|}
\hline Plankton & Tank & Phylum & Class & Genera \\
\hline \multirow[t]{15}{*}{ Phytoplankton } & \multirow[t]{9}{*}{ Tank 1} & \multirow[t]{9}{*}{ Ohcrophyta } & \multirow[t]{8}{*}{ Bacillariophyceae } & Nitzschia \\
\hline & & & & Navicula \\
\hline & & & & Licmophora \\
\hline & & & & Amphora \\
\hline & & & & Cymbella \\
\hline & & & & Radiolarian \\
\hline & & & & Cyclotella \\
\hline & & & & Leptocylindrus \\
\hline & & & Coscinodiscophyceae & Cosinodiscus \\
\hline & \multirow[t]{2}{*}{ Tank 1} & \multirow[t]{2}{*}{ Cynophyta } & \multirow[t]{2}{*}{ Cynophyceae } & Gomphoperia \\
\hline & & & & Oscillatoria \\
\hline & \multirow[t]{4}{*}{ Tank 1} & \multirow[t]{4}{*}{ Chlorophyta } & \multirow[t]{4}{*}{ Chlorophyceae } & Borodinellopsis \\
\hline & & & & Chlorella \\
\hline & & & & Chlamydomonas \\
\hline & & & & Tetraselmis \\
\hline Zooplankton & Tank 1 & Rotifera & Brachionidae & Brachionus \\
\hline \multirow[t]{5}{*}{ Protozoa } & \multirow[t]{5}{*}{ Tank 1} & Ciliophora & Euplotidae & Euplotes \\
\hline & & Ciliophora & Vorticellidae & Vorticella \\
\hline & & Ciliophora & Parameciidae & Paramecium \\
\hline & & Euglenoidea & Euglenaceae & Euglena \\
\hline & & Ciliophora & Ciliatea & Cilliate \\
\hline Nematode & Tank 1 & Nematoda & & Nematode \\
\hline
\end{tabular}

(Medina and Neis 2007). These EPS were known to have significant effect on the physiochemical properties of the microbial aggregates including structure, surface charge, flocculation, settling properties, dewatering and absorptive capacity Sheng et al. (2010). The floc itself also as the bioremediation agent is able to stick the detritus from the wastes together with other organisms such as protozoa and zooplankton during bioflocculation and bacteria in the floc take up ammonia in the water which mostly comes from the metabolic waste of shrimp and convert it into microbial protein. Hargreaves (2013) discovered that bioflocs are accumulation of algae, bacteria, protozoan, and other kinds 
Table 3 Type of microorganisms identified as aggregates in the biofloc in Tank 2

\begin{tabular}{|c|c|c|c|c|}
\hline Plankton & Tank & Phylum & Class & Genera \\
\hline \multirow[t]{5}{*}{ Phytoplankton } & \multirow[t]{5}{*}{ Tank 2} & \multirow[t]{2}{*}{ Ohcrophyta } & Bacillariophyceae & $\begin{array}{l}\text { Nitzschia } \\
\text { Leptocylindrus } \\
\text { Navicula } \\
\text { Cyclotella } \\
\text { Melosira } \\
\text { Licmophora } \\
\text { Cymbella }\end{array}$ \\
\hline & & & Coscinodiscophyceae & Cosinodiscus \\
\hline & & Cynophyta & Cynophyceae & $\begin{array}{l}\text { Oscillatoria } \\
\text { Gomphosperia } \\
\text { Gloeocapsa }\end{array}$ \\
\hline & & Chlorophyta & Chlorophyceae & $\begin{array}{l}\text { Chlorella } \\
\text { Borodinellopsis } \\
\text { Scenedesmus } \\
\text { Tetraselmis }\end{array}$ \\
\hline & & Dinophyta & Dinophyceae & $\begin{array}{l}\text { Protoperidinium } \\
\text { Alexandrium }\end{array}$ \\
\hline Zooplankton & Tank 2 & $\begin{array}{l}\text { Arthropoda } \\
\text { Rotifera }\end{array}$ & $\begin{array}{l}\text { Copepoda } \\
\text { Brachionidae }\end{array}$ & $\begin{array}{l}\text { Copepod } \\
\text { Branchius }\end{array}$ \\
\hline Protozoa & Tank 2 & $\begin{array}{l}\text { Sarcomastigophora } \\
\text { Ciliophora } \\
\text { Ciliophora } \\
\text { Ciliophora } \\
\text { Euglenoidea } \\
\text { Ciliophora }\end{array}$ & $\begin{array}{l}\text { Radiolaria } \\
\text { Euplotidae } \\
\text { Parameciidae } \\
\text { Ciliatea } \\
\text { Euglenaceae } \\
\text { Vorticellidae }\end{array}$ & $\begin{array}{l}\text { Radiolarian } \\
\text { Euplotes } \\
\text { Paramecium } \\
\text { Cilliate } \\
\text { Euglena } \\
\text { Vorticella }\end{array}$ \\
\hline Nematode & Tank 2 & Nematoda & & Nematode \\
\hline
\end{tabular}

of particulate organic matter such as feces and uneaten feed which are held together in a loose matrix of mucus secreted by bacteria and bound by filamentous algae or held by electrostatic attraction. During siphoning process, it can also be seen that the waste at the bottom of the tank was aggregated in small rounded shape, which means the biofloc microorganisms work in settling down the detritus and acted as the bioremediation agent in neutralizing the pollutant in the bottom of the tank and makes the condition of water optimum. For the saprophytes group or the organisms obtaining nutrients from the dead organic matter, heterotrophic bacteria is in this classification. Heterotrophic bacteria identified from the study are Aeromonas spp and Pseudomonas spp. Heterotrophic bacteria used the organic compound from the organic matter left in the tank as the sources of energy and food which contrast with the autotrophic organisms such as phytoplankton and algae. Protozoa identified in the biofloc treatment tank such as ciliate, vorticella, euplotes and paramecium also classified as saprophytic protozoa as absorb organic matter through their cell wall for food and takes $40 \%$ of the nutrients for the production of protozoan biomass (Merriam Co 1913; Lal 2006). All of these saprophytic microorganisms acted as bioremediation agents in neutralizing the nutrients (ammonia, nitrite and nitrate) from the wastes of uneaten feed and shrimp's fecal secretion that produced ammonia product. The denitrifying bacteria, Pseudomonas sp., was identified in the bioflocculation that worked to convert the nitrates $\mathrm{NO}^{3-}$ into gaseous nitrogen; $\mathrm{N}_{2}$ makes the water condition less toxic and maintains the water quality (Schramm et al. 1999). This bacteria also will convert the nitrates in the water to the beneficial protein for shrimp consumption besides getting the food from the pellet given. These are proved through Hargreaves's (2013) study in biofloc system, whereas some of the nitrogen is incorporated into the bacterial cells that become the main component of biofloc, shrimp consumption of this microbial protein will effect for a second time and contribute to shrimp growth. Zooplankton, protozoa and protozoa parasite are classified under the algae grazer category. The organisms identified in the bioflocculation were such as nematode, gastrotrich, euplotes protozoa, vorticella 
Table 4 Type of microorganisms identified as aggregates in the biofloc in Tank3

\begin{tabular}{|c|c|c|c|c|}
\hline Plankton & Tank & Phylum & Class & Genera \\
\hline \multirow[t]{13}{*}{ Phytoplankton } & \multirow[t]{13}{*}{ Tank 3} & \multirow[t]{6}{*}{ Ohcrophyta } & \multirow[t]{5}{*}{ Bacillariophyceae } & Nitzschia \\
\hline & & & & Leptocylindrus \\
\hline & & & & Cyclotella \\
\hline & & & & Licmophora \\
\hline & & & & Navicula \\
\hline & & & Coscinodiscophyceae & Cosinodiscus \\
\hline & & \multirow[t]{3}{*}{ Cynophyta } & \multirow[t]{3}{*}{ Cynophyceae } & Oscillatoria \\
\hline & & & & Gomphosperia \\
\hline & & & & Gloeocapsa \\
\hline & & \multirow[t]{2}{*}{ Chlorophyta } & \multirow[t]{2}{*}{ Chlorophyceae } & Chlorella \\
\hline & & & & Borodinellopsis \\
\hline & & \multirow[t]{2}{*}{ Dinophyta } & \multirow[t]{2}{*}{ Dinophyceae } & Protoperidinium \\
\hline & & & & Alexandrium \\
\hline \multirow[t]{3}{*}{ Zooplankton } & \multirow[t]{3}{*}{ Tank 3} & Arthropoda & Copepoda & Copepod \\
\hline & & Rotifera & Brachionidae & Branchius \\
\hline & & Gastrotricha & Chaetonotida & Gastrotrich \\
\hline \multirow[t]{6}{*}{ Protozoa } & \multirow[t]{6}{*}{ Tank 3} & Euglenoidea & Euglenaceae & Euglena \\
\hline & & Ciliophora & Vorticellidae & Vorticella \\
\hline & & Ciliophora & Euplotidae & Euplotes \\
\hline & & Ciliophora & Parameciidae & Paramecium \\
\hline & & Ciliophora & Ciliatea & Cilliate \\
\hline & & Sarcomastigophora & Radiolaria & Radiolarian \\
\hline Nematode & Tank 3 & Nematoda & & Nematode \\
\hline
\end{tabular}

Fig. 4 Density of microorganisms composition identified from the bioflocculation in the water column of treatment culture tanks for Day of culture, DOC11

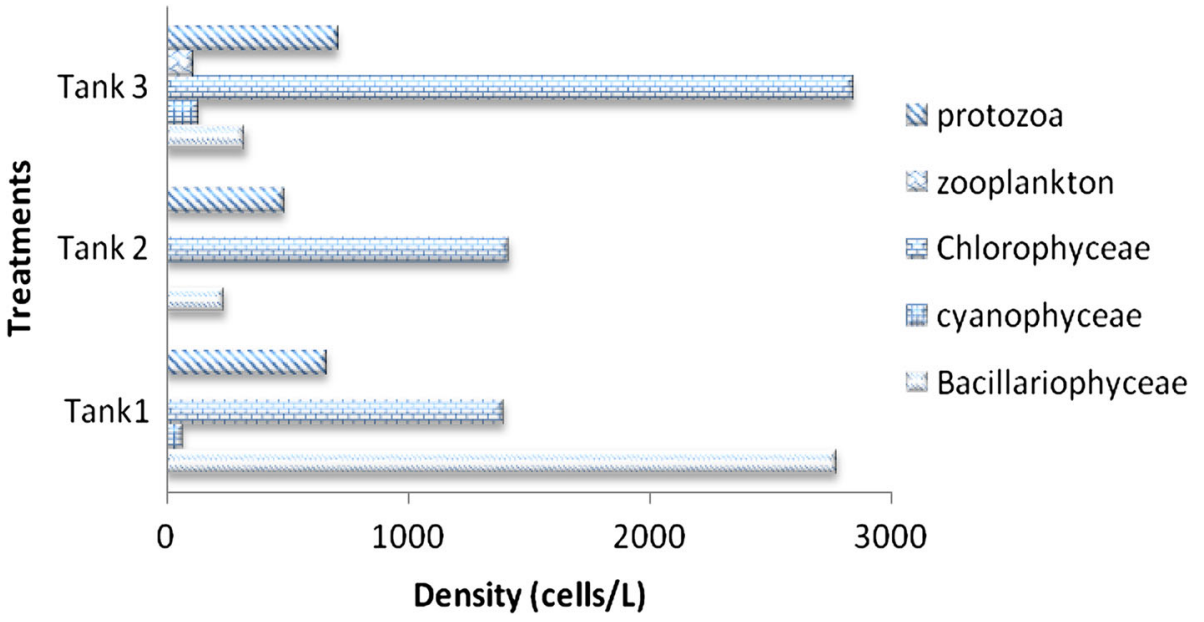

protozoa, ciliate, rotifer and copepod which in dense composition as higher food from algae and phytoplankton types were available in the biofloc treatment tank (Hargreaves 2013). During culture starting from DOC11 to DOC93 (Figs. 4, 5, 6, 7, 8, 9, 10), algae from three different classes indentified to dominate the biofloc culture treatment are Chlorophyceae (Green algae), Bacillariophyceae (Diatoms), Cyanophyceae (Blue green algae) and occasionally from
Dinophyceae (Dinoflagellates) class. This finding is same as the studies by Galvez (2015) and Schrader et al. (2011) which found out that the most abundant algae in this biofloc study came from cyanobacteria class followed by Chlorophyta, Heterokontophyta, Euglenophyta and Dinophyta. The organisms classified under pathogenic group identified are protozoa that are harmful to the shrimp and the pathogenic bacteria Vibrio sp. such as Vibrio alginolyticus that 
Fig. 5 Density of microorganisms composition identified from bioflocculation in the water column of treatment culture tanks for Day of culture, DOC17

Fig. 6 Density of microorganism composition identified from the bioflocculation in the water column of treatment culture tanks for Day of culture, DOC30
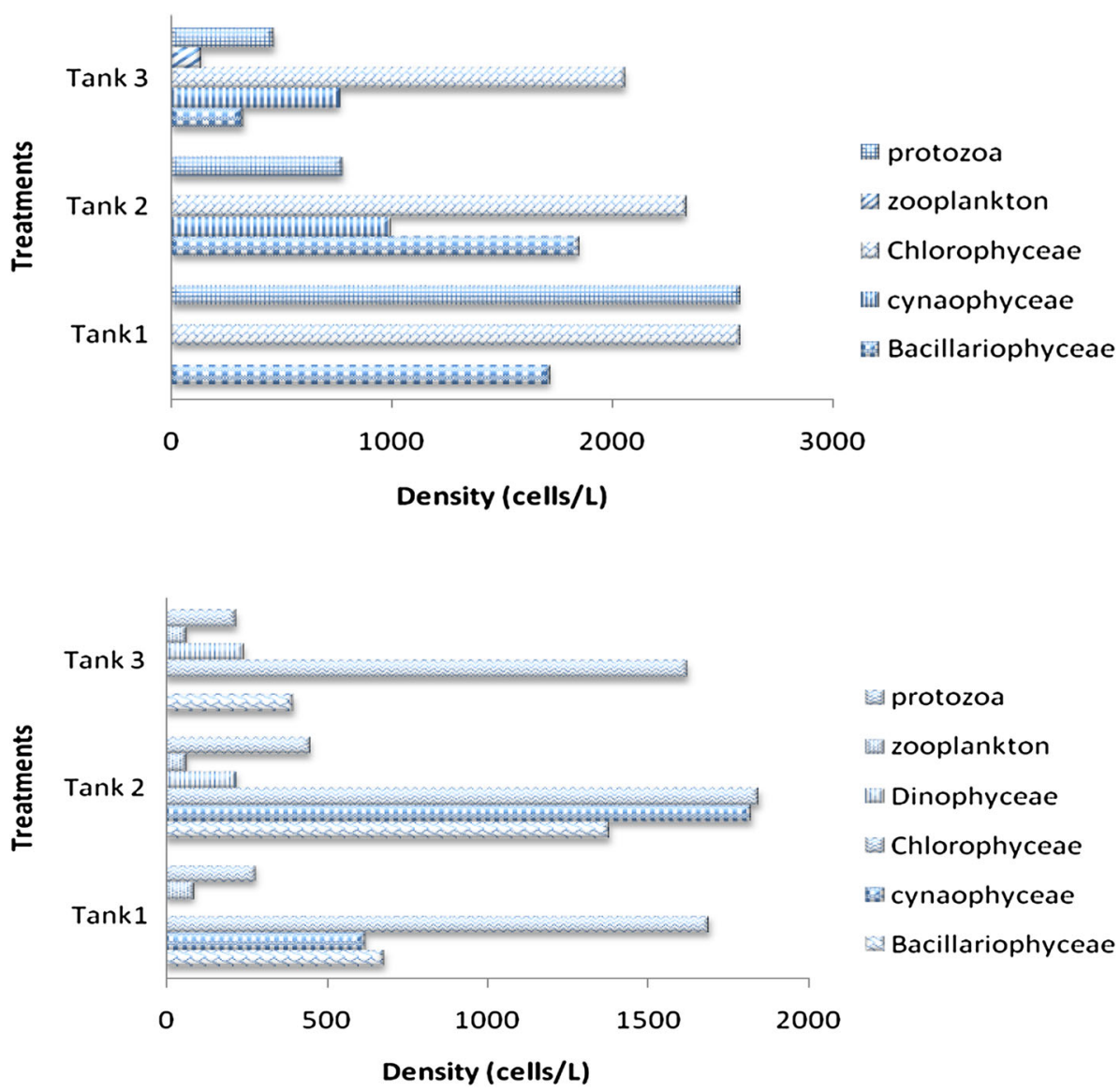

Fig. 7 Density of microorganism composition identified from the bioflocculation in the water column of treatment culture tanks for Day of culture, DOC58

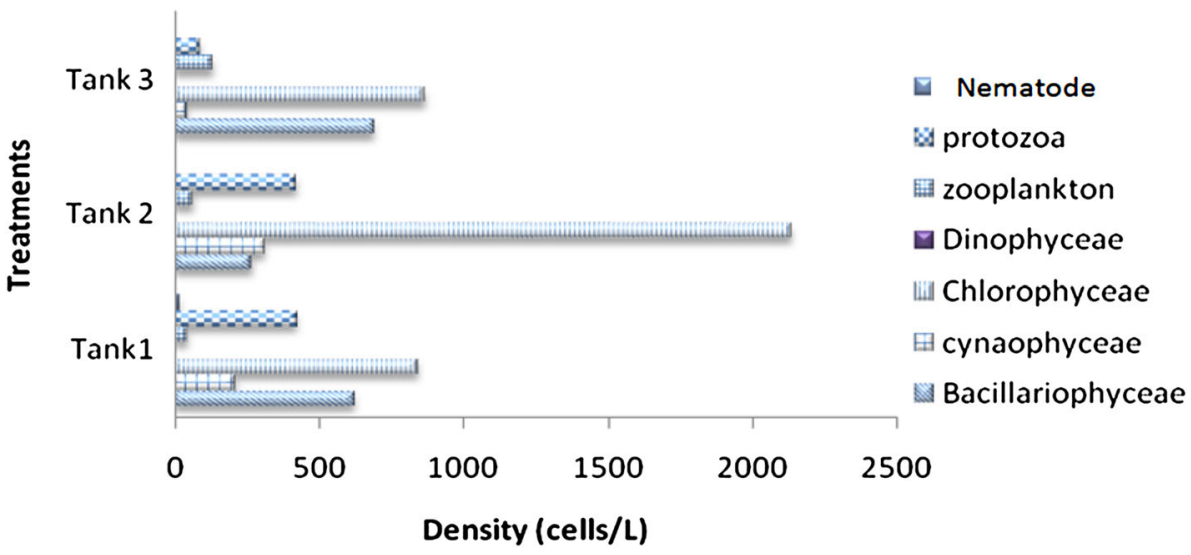

can give infection to the shrimp as suggested by Wei and Wendy (2012). The Vibrio sp. was also identified in the biofloc aggregation but in less CFU number. These were not lethal to the shrimps as it is being controlled by the biofloc itself through higher diversity of phytoplankton and algae and also can compete with dominant number of hetero- trophic bacteria. Refer to study done by Emerenciano et al. (2013) they discovered that the natural probiotic in the biofloc could internally or externally against the Vibrio sp. and ectoparasite from giving harmful to the shrimp. Competing with the dominant heterotrophic bacteria and nitrifying bacteria for the essential nutrients such as nitrogen 
Fig. 8 Density of microorganism composition identified from the bioflocculation in the water column of treatment culture tanks for Day of culture, DOC65

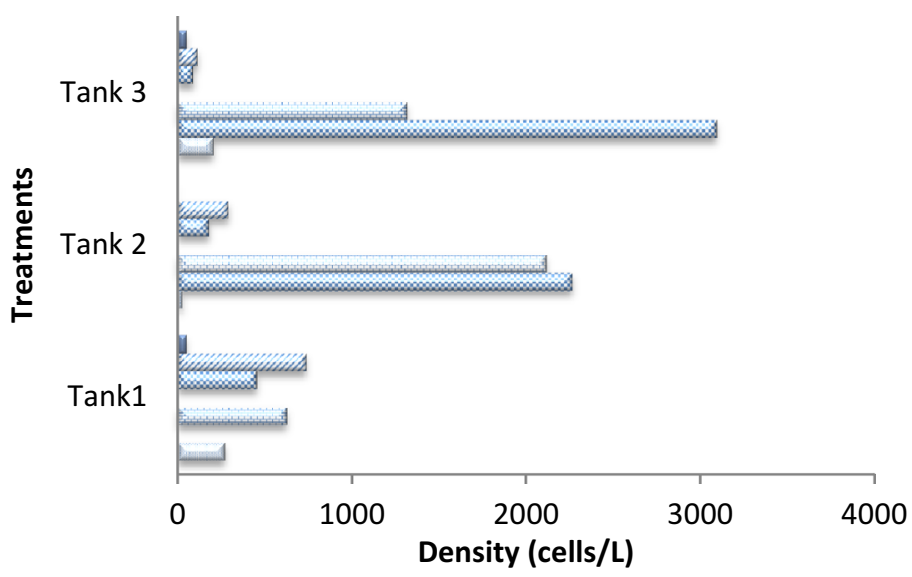

$\square$ nematode

«aprotozoa

w zooplankton

Dinophyceae

보표 Chlorophyceae

« cynaophyceae

$\checkmark$ Bacillariophyceae
Fig. 9 Density of microorganism composition identified from the bioflocculation in the water column of treatment culture tanks for Day of culture, DOC76

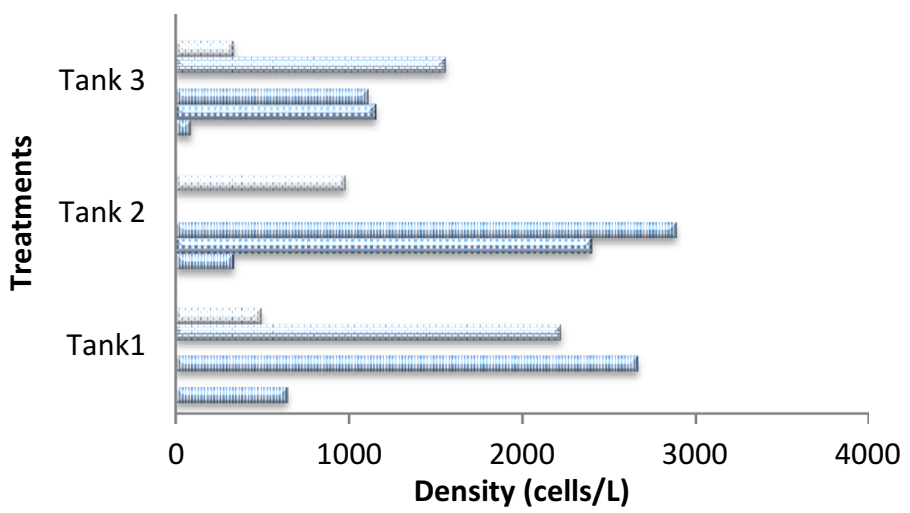

$\square$ nematode

protozoa

봄 zooplankton

$\triangle$ Dinophyceae

Chlorophyceae

« cynaophyceae

Bacillariophyceae
Fig. 10 Density of microorganism composition identified from the bioflocculation in the water column of treatment culture tanks for Day of culture, DOC93

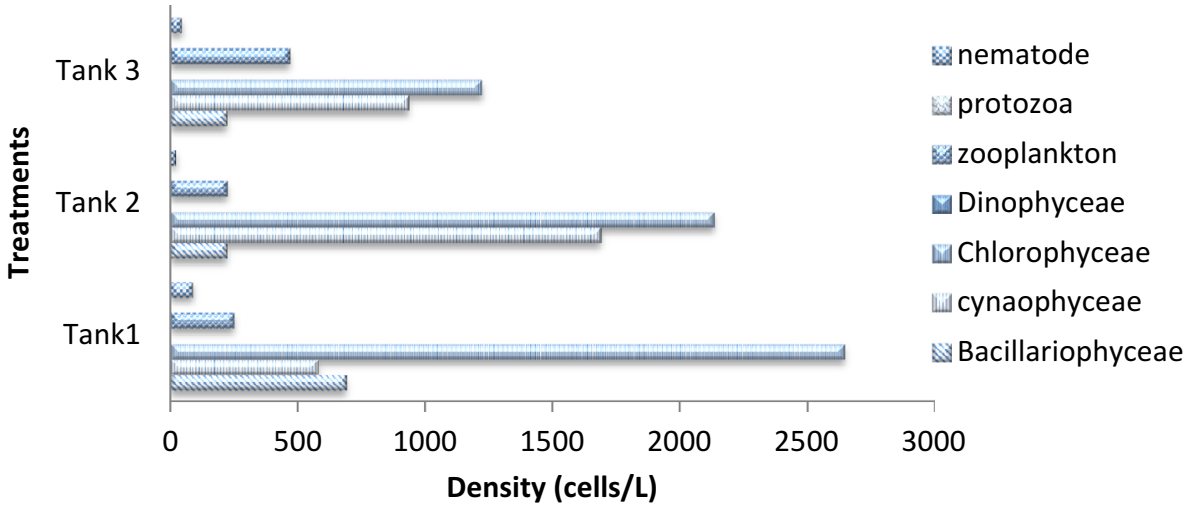

also will limit the Vibrio sp. group from uncontrolled growth (Emerenciano et al. 2013).

\section{Conclusion}

Bioflocculation is a promising technology towards friendly aquaculture environment. In fact, it can supply additional diet for shrimp's consumption from the biofloculant of a variety microorganisms identified in the floc; biofloc also were recognized to be efficient and successful as a bioremediation and biodegradation agent for maintaining the water quality in the close aquaculture system with the zero water exchange.

Acknowledgments The author would like to thank private hatchery (AB Hatchery Sdn. Bhd) for PL shrimp supply for this research project. Authors also would like to thank Fisheries officer Mr Hanif, Assistant Science officer Mr. Sabri Muda and Research Officer Mr. Ikhwan Zakariah and all the hatchery officers and staffs of Institute of Tropical Aquaculture, Universiti Malaysia Terengganu for all the assistance and guidance throughout the research period. 
Open Access This article is distributed under the terms of the Creative Commons Attribution 4.0 International License (http:// creativecommons.org/licenses/by/4.0/), which permits unrestricted use, distribution, and reproduction in any medium, provided you give appropriate credit to the original author(s) and the source, provide a link to the Creative Commons license, and indicate if changes were made.

\section{References}

American Public Health Association. APHA (1989) Phytoplankton counting technique. In: Standard methods for the examination of water and wastewater, pp 10-23

Avnimelech Y (2009) Biofloc technology—a practical guide book. The world Aquaculture Society, EUA, BatonRouge, Louisiana

Das S (2014) Microbial biodegradation and bioremediation. Laboratory of Environmental Microbiology and Ecology (LenME). National Institute of Technology, Rourkela Odisha (Elsevier Book First Edition)

Das S, Lyla PS, Khan SA (2006) Marine microbial diversity and ecology: present status and future perspectives. Curr Sci 90(10):1325-1335

Dash HR, Das S (2012) Bioremediation of mercury and importance of bacterial mergenes. Int Biodeterior Biodegrad 75:207-213

Emerenciano M, Gaxiola G, Gerard C (2013) Biofloc Technology (BFT): a review for aquaculture application and animal food industry. Biomass Now-Cultiv Util. doi:10.57772/53902

Galvez AO (2015) Plankton communities in shrimp monoculture, integrated biofloc system. Global Aquaculture Advocate MAY/ JUN 2015

Hargreaves JA (2006) Photosynthetic suspended-growth systems in aquaculture. Aquac Eng 34:344-363

Hargreaves JA (2013) Biofloc production systems for aquaculture. SRAC, Southern Regional Aquaculture Center Publication. No. 4503, pp 1-12

Karigar CS, Rao SS (2011) Role of microbial enzymes in the bioremediation of pollutants: a review. Enzym Res. doi:10.4061/ 2011/805187
Lal R (2006) Encyclopedia of soil science. In: Griffiths BS (ed) Nature. Scottish Crop Research Institute, Invergowrie. doi:10. 1081/E-ESS-120042737

Medina M, Neis U (2007) Symbiotic algal bacterial wastewater treatment: effect of food to microorganism ratio and hydraulic retention time on the process performance. Water Sci Technol 55(11):165-171

Merriam Co G (1913) Protozoa, their role and impact on aquaculture. Webster Revised Unabridged Dictionary, Encyclopedia Dictionary (Aquaculture) published

Panigrahi A, Sundaram M, Ravichandran P, Gopal C, (2014) Microbial soup-Eco based approach for shrimp culture and management. CIBA (Indian Council of Agricultural Research) ENVIS Centre Newsletter vol 12:2. 2 Apr-Jun 2014

Schrader KK, Green BW, Perschbacher PW (2011) Development of phytoplankton communities and common off-flavors in a biofloctechnology system used for the culture of channel catfish (Ictaluruspunctatus). Aquac eng 45:118-126

Schramm A, de Beer DA, Van den Heuvel S, Ottengraf S (1999) Microscale distribution of populations and activities of Nitrosospira and Nitrospira spp. along a macroscale100 sustainable aquaculture technique gradient in a nitrifying bioreactor: quantification by in situ hybridization and the useofmicrosensors. Appl Environ Microbiol 65:3690-3696

Schneider O, Sereti V, Eding EH, Verreth JAJ (2005) Analysis of nutrient flows in integrated intensive aquaculture systems. Aquac Eng 32:379-401

Sheng G, Yu H, Li X (2010) Extracellular Polymeric Substances (EPS) of microbial aggregates in biological wastewater treatment systems: a review. Biotechnol Adv 28(6):882-894

Stelting S, Burns RG, Sunna A, Visnovsky G, Bunt C (2010) Immobilization of Pseudomonas sp. strain ADP: a stable inoculant for the bioremediation of atrazine. In: 19th World congress of soil science, soil solutions for a changing world, Brisbane, Australia

Wei LS, Wendy W (2012) Chracterization of vibrio alginolyticus isolated from white leg shrimp (Litopenaeus vannamei) with emphasis on its antibiogram and heavy metal resistance pattern. Verterinarski Arh 82(2):221-227 